\title{
Interkulturní obraz Indie v slovenské literatuře
}

\author{
Miloš Zelenka (České Budějovice)
}

Róbert Gáfrik: Zobrazovanie Indie v slovenskej literatúre. Bratislava: Veda, 2018. 140 s. ISBN 978-80-2241635-1.

Studium meziliterární sítě mezi strukturně a typologicky odlišnými kulturami a literaturami bud' zůstává v rovině metodologických proklamací, nebo se empiricky omezuje na bibliografický výčet překladů či nástin recepčního horizontu. Problém spočívá nejen v mentální a geografické vzdálenosti badatelského subjektu k předmětu zkoumání, ale i v interdisciplinaritě výzkumných přístupů, které v osobitém poměru slučují postkoloniální teorii, orientalistiku, hermeneutickou filozofii a imagologický způsob uvažování. Podle jednoho z hlavních iniciátorů interkulturní komparatistiky Earla Minera má tento výzkum směřovat k pochopení, resp. k vysvětlení kulturních odlišností či ,jinakostí“ těch literárních tradic a poetik, mezi nimiž existuje prokazatelný rozdíl vyplývající z geografické (kontinentální) a poetologické vzdálenosti a „ne-podobnosti“. Nejde tu o registraci genetických kontaktů nebo typologických souvislostí, ale o vytvoření takového teoretického diskursu umožňujícího vyslovit obecně platné výroky, které by dekonstruovaly axiomata západní (evropsko-americké) literární vědy. Potřebu odideologizovaného vidění ,jinakosti“ či „cizosti“ v různé míre proklamují právě soudobé koncepty interkulturní komparatistiky, které předpokládají, že „cizí“ kulturní prostor vzniklý v naší mysli sám o sobě neexistuje, protože se texty komplementárně vytvářejí jako odraz reálné skutečnosti, jako výraz jisté fikce. Lze tu připomenout např. teorii mentálních map Franca Morettiho, která prostřednictvím redukce motivických prvků a jejich prostorové abstrakce, konstruuje meziliterární sítě a tím upozorňuje na relevantní, mnohdy skryté vlastnosti textu. Porozumění literatuře se zde neodehrává prostřednictvím popisu jednotlivých textů, ale analyzováním „velkých dat“ odhalujících struktury literárních jevů.
Z tohoto metodologického přístupu vychází interdisciplinárně profilovaná monografie Roberta Gáfrika Zobrazovanie Indie v slovenskej literatúre zkoumající obraz indické kultury a identity v kontextu slovenských představ o tomto rozsáhlém regionu od začátku 19. století až po současnost. Gáfrik, který nepíše tradiční dějiny slovensko-indických politických a kulturních vztahů, si je vědom, že obraz „cizi“ krajiny nemá oporu v konkrétní geografii, ale spíše v mentální, psychické představě čtenáře. Zajímá ho proto nejen, jak je tato indická krajina reflektována v slovenském literárněkritickém a kulturním diskurzu, ale i to, nakolik kritické postupy, které převažují v tzv. západní literární vědě, mohou být produktivní při rekonstrukci fascinujícího zájmu Evropanů o fenomén Indie. Gáfrik jako komparativně vyhraněný literární badatel se projevuje jako zasvěcený znalec recepce Orientu a orientalismu v západní Evropě, zejména v anglosaském a německém prostředí. Této problematice se dlouhodobě věnoval už v předchozích publikacích jako Hra s cudzou kultúrou. K recepcii staroindických látok a motívov v nemeckej literatúre (2009) a Od významu k emóciám. Úvaha o prinose sanskrtskej literárnej teórie do diskurzu západnej literárnej vedy (2012), v nichž jednak detailněji shrnul zastoupení indických látek v německé kultuře, jednak přesněji konkretizoval západoevropskou, zejména německou podobu orientalismu, která se stala jedním z filozofických zdrojů německé romantiky tím, že obraz Indie prezentovala jako krajinu ideální pravlasti a nezkažené morálky. Populárně-naučný pendant $\mathrm{k}$ této monografii tvoří Farebná India (2017), kterou Gáfrik vydal společně se slovenskými indology Dušanem Deákem a Annou Rácovou. Jedná se o graficky reprezentativní kroniku s literárními 
ukázkami, přibližující širší veřejnosti minulou a současnou Indii.

Rozsahem nevelká monografie, jejíž části byly časopisecky publikovány v letech 2008-2017, se skládá ze šesti kapitol s úvodní částí, jmenným rejstř́íkem a ediční poznámkou. Text i přes parciálnost jednotlivých pasáží vzniklých k různým účelům v časovém úseku jednoho desetiletí, nepůsobí torzovitě a fragmentárně, naopak vytváří myšlenkově a kompozičně propojený celek, který ve svém metodologickém incipitu India a Slovensko v širšich kultúrnych súvislostiach mapuje mezikulturní komunikaci mezi Evropou a Indií, zájem o studium sanskrtu, vznik srovnávací jazykovědy, zejména připomíná rozdíl mezi koloniálními výboji Anglie a filozoficko-estetickým osvojováním německých osvícenců a modernistů. Gáfrik dokazuje nutnost existence středoevropského vnímání orientalismu, jeho jistou specifičnost vyplývající ze skutečnosti, že střední Evropa nemá koloniální minulost a sama byla $\mathrm{v}$ minulosti nositelem orientalismu.

Vlastní literárněhistorický výklad začíná druhou kapitolou „Objavenie“ Indie v slovenskej literatúre 19. storočia, která dokumentuje zájem o indickou kulturu v dílech klíčových slovenských národních buditelů Jana Kollára a Ludovíta Štúra, zajímajících se o sanskrtský gramatický systém a staroindickou mytologii. Následující kapitola zachycuje návštěvu indických maharadžů v meziválečném období v Pieštanech, zejména přibližuje životní osudy slovenské intelektuálky ruského původu Viery Lubošinské (prožila sedm let za druhé světové války v Indii, kde si vedla zápisky pod názvem Indický dennik) a utopistického kněze Jána Maliarika, který se v románu Sulabhá (vydán až roku 1992) orientoval na duchovní hledání absolutní pravdy a zajištění celosvětového univerzálního státu a trvalého míru. V případě socialistického období 19451989 za velmi cenné považuji Gáfrikovo zjištění, že obraz Indie v tomto období nebyl ideologicky monolitní, nýbrž kolísal mezi naivně romantickým pohledem a rigorózně socialistickým, v němž se paradoxně navzdory postkoloniální situaci po druhé světové válce vyjevovaly formy latentního kolonialismu, tj. přesvědčení o nut- né kolonializaci třetího světa v podobě vítězné revoluce. Je však paradoxní, že zrušení ideologických bariér a svobodná možnost cestování se odrazilo ve vzniku nových cestopisů a v intenzivnější literární reflexi zážitků, přesto demokratizační zpřístupnění exotiky širší veřejnosti však neznamenalo zachování literárně-estetických kvalit textů z předchozího období.

Gáfrikova monografie je dokladem vysoké úrovně slovenské indologie, ale i domácí komparativní tradice, autor píše odborným, avšak srozumitelným stylem, který se vyhýbá složitému teoretizování, dokáže pojmenovat problém a přehledně ho vysvětlit. Teoretické pasáže podkládá literárněhistorickou argumentací dosvědčující znalost indické kultury nejen v kulturních souvislostech, ale i „zevnitř“”, z hlediska životní zkušenosti pozorujícího subjektu. Monografie zatím představuje jen náčrt problematiky mezikulturního dialogu mezi Indií a malou středoevropskou literaturou. Lze předpokládat, že vědomí odlišnosti indické a slovenské kultury povede v dalším výzkumu $\mathrm{k}$ důslednějšímu studiu odlišných funkcí tematických celků a žánrových struktur mezi oběma literaturami, které jsou i přes svou „ne-podobnost“ či „ne-příbuznost“ v obou literárních systémech dominantní. Jak upozorňuje klasik mezikulturního bádání Earl Miner, v těchto výzkumech třeba přihlédnout ke skutečnosti, že absence některých témat a žánrů může být nahrazována existencí jiných žánrů a témat v odlišných souvislostech. Rovněž bude třeba věnovat větší pozornost otázce specifičnosti imagotypních struktur vznikajících v uměleckých a publicistických textech už vzhledem k tomu, že naše poznání „jiné“, resp. „cizi““ země ovlivňují a manipulují především média, a nikoli literatura jako umění. Jsou tudíž tyto imagotypní struktury odlišné od stereotypů utvářených ve věcných textech neliterární povahy? Právě sémantický prostor mezi referenčním vztahem, kterým disponujî́ utilitární texty, a možnostmi umělecké literatury generovat fiktivní světy s vlastními koncepty ,jinakosti“, determinuje imagologický diskurs, který je do jisté míry nezávislý na vnější realitě. Přesto je nutné zachovat - a toho si je Gáfrik vědom - jistou skepsi relativizující „pravdivost“ našeho 
poznání. Studium vzájemnostních představ, vě- včetně imagologického způsobu myšlení, musí domé hledání jinakosti prostřednictvím textových stát analýza kulturní podmíněnosti literárněvědobrazů cizího, má totiž ideologický základ, který ných, sociologických a sémiotických diskursů, vždy hájí zájmy konkrétních jednotlivců či sku- které omezují transfer mezikulturní různorodosti pin. Klíčovou se proto v mezikulturních reflexích, do nové „globální“ jednoty.

\section{prof. PhDr. Miloš Zelenka, DrSc.}

Katedra slovanských jazyků a literatur

Pedagogická fakulta, Jihočeská univerzita

Jeronýmova 10, 37115 České Budějovice, Česká republika

zelenka@pf.jcu.cz 